America has become like the Rich Man in the biblical parable of Lazarus: blind to and uncaring about the plight of its citizens of darker hue. A blindness rooted in a soul-sickness that allows it to rest easy, complacent and even hardened to the rampant suffering among us, ... a suffering that is conveniently hidden from sight and largely absent from public discourse.

I am convinced that as necessary as changed social practices such as better police training and body cameras may be, and as important as a vigorous enforcement of civil rights laws is, these will be limited and even ineffective without a deeper conversion, without a healing of the soul, without a profound revolution of values, that is, without attending to the deeper recesses of the human spirit that are the realm of religious faith and spirituality. That is why I became and remain a faith activist for racial justice.

I offer this as one illustration of both the contribution and the necessity of "doing public theology," that is, of addressing issues of public concern, urgency, and import to a religiously pluralistic and diverse audience of fellow members of a civic community in a way that is accessible to people of any or no faith tradition or commitment while rooted in and inspired by one's own faith perspective, commitments, and beliefs.

BRYAN N. MASSINGALE

Fordham University

\title{
Doing Theology in the Public Sphere
}

There is nothing more wonderful, or more satisfying, than writing about God and the things of God, and sharing that writing in a public space. Public theological writing-whether it be for a journal of opinion, a catechetical resource, or a blog-responds to the gospel call to "proclaim on the housetops" what you hear whispered (Matt 10:27), and in its own way participates in the Christian calling to "set on a lampstand" that light that gives glory to God (Matt 5:15). There can also be great satisfaction in shaping religious publications and designing and speaking at live events during which people interact around theological subjects. All this is very good.

Rita Ferrone is an independent scholar and author of several books about liturgy, including Liturgy: Sacrosanctum Concilium (New York: Paulist Press, 2007). She serves as general editor of The Yale ISM Review, and is a contributing editor and columnist for Commonweal magazine. She blogs at dotCommonweal and the Pray Tell Blog. 
Nevertheless, the public spaces we have for doing theology are also fraught with difficulties. From 1988 to 2013 I gave institutes around the country with the North American Forum on the Catechumenate. I remember one institute at which a young seminarian objected to what the presenters were saying because we were "too liberal." After first condescending to my copresenter, a woman religious of more than thirty years, for "not understanding consecrated life," he then criticized me for having the temerity to quote from ritual studies sources as well as magisterial ones in exploring the theology of Christian initiation. He finally refused to adopt the postures and gestures the rest of us took at liturgy, and for the remainder of the talks he sat at the back of the room with a book by Thérèse of Lisieux held up over his face! Like a child who puts his fingers in his ears, he was no longer willing to hear what we had to say. He was, as expected, ordained at some later date, and I understand he is a "very good priest" today. But we had to bear with him in his immaturity and at the same time not give in to it. There were, after all, other people in the room who were there to learn.

\section{Problems of the Catholic Blogosphere}

The cloak of anonymity afforded by the Internet makes conflicts even more prevalent and intense online than they are in face-to-face events. Father Thomas Rosica, director of Salt and Light Catholic Media Foundation and a public relations consultant for the Vatican, has called the Catholic blog world "a cesspool of hatred, venom, and vitriol, all in the name of defending the faith!" His response was promptly critiqued by those who trade in partisan attacks themselves; but the description he offered was too true to life to be dismissed lightly. He went on to say that "often times the obsessed, scrupulous, self-appointed, nostalgia-hankering virtual guardians of faith or of liturgical practices are very disturbed, broken, and angry individuals, who never found a platform or pulpit in real life and so resort to the Internet and become trolling pontiffs and holy executioners! In reality they are deeply troubled, sad and angry people." 6

My particular public space (I write about liturgy) is crowded with angry voices, partisans, and cranks. They sometimes even form "postmodern tribes," the soccer hooligans of Catholicism. Writers who publish in print media catch less flak, because letters to the editor are curated and screened for civility, but exchanges on blogs occur in real time and are often acrimonious. Because liturgy is embodied theology, a great deal is at stake in these

${ }^{6}$ Catholic News Service, "Vatican PR Aide Warns Catholic Blogs Create 'Cesspool of Hatred,'” Crux, May 17, 2016, https://cruxnow.com/cns/2016/05/17/vatican-pr-aidewarns-catholic-blogs-create-cesspool-of-hatred/. 
discussions. Yet the noise and shouting can obscure what the deeper issues really are.

The problem is not a multiplicity of opinions. Liturgy affects the whole Catholic community, so naturally it interests many people, and there are as many opinions about it as there are Catholics. But there is something more going on here. When Aidan Nichols famously wrote that liturgy is "too important to leave to the liturgists" (a sentiment John Baldovin rightly observed to be one that no liturgist would disagree with), it was, alas, not a neutral observation. It became a rallying cry for a wholesale effort to relativize, undermine, and redirect the liturgical reforms of the Second Vatican Council. Those reforms came out of a mainstream scholarly consensus view of the history and the theology of Catholic liturgical rites. They still enjoy the backing of most scholars in the field. Yet they have been under attack on many levels, especially by non-liturgists, as a small minority attempts to "right the rites" by making them more like the preconciliar liturgies they replaced.

\section{A History of Conflict}

The roots of these conflicts go back to the Second Vatican Council itself, 7 and are embodied in unresolved tensions in the documents the produced. As George Lindbeck noted as long ago as 1976, the council documents broke new ground while retaining a past that does not always jibe well with the newer vision they enunciated. ${ }^{8}$ This is true of the liturgy constitution, which holds a delicate balance. Latin and the vernacular are both affirmed. Tradition and progress are both commended. New musical compositions and instruments are welcomed, and Gregorian chant is endorsed. What has come back to haunt us especially, however, as historian Massimo Faggioli has pointed out, is that the liturgy constitution embodies an ecclesiology more radically renewed than that which is found in the council documents produced after it: "It has been said that 'Vatican II stopped halfway.' The liturgy constitution, Sacrosanctum Concilium, represents the first half of this way. ... The later developments of the ecclesiological debate at Vatican II leave the impression of an interruption of this theological stream in favor of

7 See Annibale Bugnini, The Reform of the Liturgy, 1948-1975 (Collegeville, MN: Liturgical Press, 1990), esp. chap. 20 for an account of outside opposition; and Piero Marini, $A$ Challenging Reform: Realizing the Vision of Liturgical Renewal (Collegeville, MN: Liturgical Press, 2007), esp. chap. 4, for an account of tensions between the Consilium and the Curia.

${ }^{8}$ George A. Lindbeck, "The Catholic Crisis," in Commonweal Confronts the Century: Liberal Convictions, Catholic Tradition (New York: Simon and Schuster, 1999), 338-45. 
a rehabilitation of the juridical dimension of the Church, in the delusional attempt to balance Vatican I and Vatican II." 9

The fact that competing groups can each find grounds of support in the documents has resulted in the splitting up of allegiances within the church during the postconciliar period, with some pressing in one direction, and others championing its opposite. Excellent leadership has been needed to steer the course of the church through this period and into a deeper level of stability. Unfortunately, that leadership has been lacking or compromised by personal ambivalence.

In the area of liturgy, the tensions escalated during the final years of the pontificate of John Paul II and the pontificate of Benedict XVI. Benedict, long known to be a critic of the reform, advocated a new hermeneutic concerning the work of the whole council. Originally he called it a "hermeneutic of reform," contrasting it with a "hermeneutic of discontinuity and rupture."10 But his most enthusiastic followers began to call it a "hermeneutic of continuity," and eventually he himself adopted the term. ${ }^{11}$ "Continuity" then became a code word for the return to preconciliar patterns of thought and practice. Benedict's motu proprio reestablishing the Tridentine rites, ${ }^{12}$ now called "the Extraordinary Form," his decisions supporting a new Roman centralization of liturgical decision-making around liturgical translations, and his sponsorship of efforts to rein in inculturation have created new tensions and ruptures.

Personal preferences approved by Pope Benedict, such as use of older vestments, ad orientem worship, and more, completed the picture. For the foot soldiers of the now-rechristened "hermeneutic of continuity," it seemed as though the entire liturgical reform was up for grabs. Angry counterreactions mocking the old vestments and railing against attempts to fashion a new "reform" cropped up in the Catholic blogosphere in their turn. But the distribution of hostility has always been lopsided, with the great majority of angry voices coming from those resentful of the conciliar reform.

9 Massimo Faggioli, True Reform: Liturgy and Ecclesiology in "Sacrosanctum Concilium" (Collegeville, MN: Liturgical Press, 2012), 62-63.

${ }^{10}$ Pope Benedict XVI, "Address of His Holiness Pope Benedict XVI to the Roman Curia Offering Them His Christmas Greetings," December 22, 2005, http://www.vatican.va/ holy_father/benedict_xvi/speeches/2005/december/documents/hf_ben_xvi_spe_20051222_ roman-curia_en.html.

${ }^{11}$ Pope Benedict XVI, Post-Synodal Apostolic Exhortation, Sacramentum Caritatis, February 22, 2007, §3, note 6, http://w2.vatican.va/content/benedict-xvi/en/apost_exhortations/documents/hf_ben-xvi_exh_20070222_sacramentum-caritatis.html.

12 Pope Benedict XVI, Apostolic Letter Given Motu Proprio, Summorum Pontificum, July 7 , 2007, http://w2.vatican.va/content/benedict-xvi/en/motu_proprio/documents/hf_benxvi_motu-proprio_20070707_summorum-pontificum.html. 


\section{Anger and Bullying}

Anger begets anger, and because we live in a society that believes abusive language is the way to vanquish enemies, a cycle of hostility online-even in theological discussions-is hardly surprising. The fires of conflict around liturgical subjects still burn hot today. ${ }^{13}$ Self-appointed watchdogs continue to denounce "liturgical abuses"; they initiate letter-writing campaigns of intimidation; they troll websites to interrupt and control discussions; they fault the liturgical reform for all manner of ills that afflict the church, recycle talking points long disproved, and trade in ad hominem attacks. ${ }^{14} \mathrm{I}$ am not talking here about serious debate or responsible investigation of critical questions, but rather classic cases of bullying.

Bullying, which seeks to dominate and to erode the victim's sense of selfworth, is not unique to Catholicism by any means. It appears in politics, sports, science, and education, as well as in religion-and within many different religious groups. Cultural anthropologist Gerard Arbuckle has identified bullying as a widespread form of violence: "Bullies seek to force others to do what they want them to do and will try all kinds of intimidation or terrorization to achieve this." 15

The open-comment format of many blog discussions offers extensive opportunities for bullying. In fact, everyone I know who has put their head above the parapet to speak favorably of the liturgical reforms of Vatican II or critically of the restorationist agenda has been shot at. The resulting atmosphere has driven a lot of sensitive, thoughtful people (scholars, pastors, and laity) straight out of the public discussion. Sadly, many who have something worthwhile to say in a public forum about liturgy fall silent for precisely this reason. They don't want to be caught in the crosshairs of an ugly attack to which they feel vulnerable-for personal reasons and sometimes professional ones.

How does one turn around such an unhappy state of affairs? Is it even worth trying?

\section{The Need for Institutions}

I think it is essential that we try to remedy this situation. In order to do so, we need to establish and support mechanisms that foster and protect

13 Pope Francis' appointment of Cardinal Robert Sarah as prefect of the Congregation for Divine Worship and the Discipline of the Sacraments has assured that tensions will persist, despite his own irenic example of liturgical presidency in the style of the reformed rites.

${ }^{14}$ One of the scapegoats continually referenced with disdain and insults even long after his death is Archbishop Annibale Bugnini (1912-82), who served as secretary of the Consilium, which crafted the liturgical reforms after the council.

15 Gerald A. Arbuckle, Violence, Society, and the Church: A Cultural Approach (Collegeville, MN: Liturgical Press, 2004), 21. See also Arbuckle, Confronting the Demon: A Gospel Response to Adult Bullying (Collegeville, MN: Liturgical Press, 2003), 17-38. 
public space for constructive theological reflection and civil dialogue-and we need to do this on the Internet. The founding of institutions would seem to be the last item on anyone's agenda with respect to the Web. But it is an inescapable demand of our times to look at how we can institutionalize standards that actually allow the best to emerge from our online platforms.

There is a myth about the Internet: that the existence of limitless platforms for speech and discussion creates an infinite opportunity for all voices to be heard. But this is a fiction. Without organizational and institutional parameters to protect public space, the loudest and meanest voices predominate, while more thoughtful voices are drowned out or silenced. What began as a public garden quickly turns into a zone for snipers or a site for dumping trash.

It's worth the effort to keep up the garden. The church needs public spaces to which a wide variety of readers may turn for accurate information, well-grounded opinion, and civil conversation about theological subjects. Websites, blogs, online magazines, and more can become part of an "ecology of institutions" 16 that forms Christians and Christian communities for a life of faith. But they will only deliver on their promise if we tend to their problems.

RITA FERRONE

Commonweal, praytellblog.com, The Yale ISM Review

${ }^{16}$ In his classic work on Christian education, Will Our Children Have Faith? John Westerhoff III described an "ecology" of six institutions that functioned in early twentieth-century US Protestantism to produce religious education, five of which had disappeared or were radically diminished by the last quarter of the century. One of these was religious publications. I think the idea of an "ecology of institutions" is a useful one and applies, mutatis mutandis, to the Catholic population as well. See John Westerhoff III, Will Our Children Have Faith? rev. ed. (Harrisburg, PA: Morehouse Publishing, 2000), 13.

\section{Public Theology: An Ever-Changing Task}

Public theology involves political and rhetorical engagement in political debates about the social consequences of Christian commitment, and prudential attempts to judge and form public debate with Christian theological

Vincent Miller is the Gudorf Chair of Catholic Theology and Culture at the University of Dayton. He is the author of Consuming Religion: Christian Faith and Practice in a Consumer Culture (New York: Continuum, 2004) and editor of The Theological and Ecological Vision of Laudato Si: Everything is Connected (London: Bloomsbury T\&T Clark, 2017). He is currently writing a book on the impact of globalization and technology upon moral responsibility, solidarity, community, and the Church. 